\title{
MIĘDZY PROBLEMEM \\ TEOLOGICZNO-POLITYCZNYM \\ A WIARA POLITOLOGA. \\ KILKA UWAG O SZKOLE STRAUSSOWSKIEJ
}

Paweł Armada

Wyższa Szkoła Filozoficzno-Pedagogiczna „Ignatianum”

\section{/// I}

Jest całkiem możliwe, że wielu adeptów politologii skłonnych byłoby postrzegać minione stulecie jako czas narodzin ich dyscypliny. Nauki polityczne moga jawić się im jako jedna z kolejnych emanacji szeroko zakrojonego przedsięwzięcia nazywanego socjologia. Utożsamiona de facto $\mathrm{z}$ nauką o polityce, socjologia polityki oznaczałaby $\mathrm{w}$ takim razie próbę prawdziwie naukowego opisania pola, w którym realizowane są „decyzje władzy zwierzchniej” (Easton 1975: 562), z nadzieją ostatecznego wyjaśnienia, tj. podania niekwestionowanej przyczyny sprawczej zjawisk zachodzących w tym „polu” (czyli pewnym fragmencie rzeczywistości ludzkiej, swego czasu ochrzczonym jako „system polityczny”), w końcu zaś prognozowania przyszłych stanów rzeczy (,,rozleci się, czy się nie rozleci?’). Wszystko to opiera się na recepcji pewnego wzorca naukowej teorii empirycznej; teorii, w której nie chodzi o „bezczynne” kontemplowanie tego, co jest, a którą kojarzy się z sukcesem nowoczesnych nauk przyrodniczych.

Kiedy ta „naukowa nauka o polityce” (Strauss 1998: 66), zasadniczo odwołująca się do tradycji myślowych pozytywizmu, wyraźnie zaczęła dominować w postawach badawczych behawiorystów czy następnie przedstawicieli nurtu public choice (w dyskursie anglosaskim), obserwator ówczesnego życia intelektualnego mógł jednocześnie oglądać bardzo żywe wystapienia uczonych sytuujących się najzupełniej a contra politologii 
uprawianej w ten sposób. Z tej perspektywy należy wziąć pod uwagę wielu autorów. Niektórzy z nich ${ }^{1}$ zasługiwaliby na bliższe studia i bardziej rozbudowaną pamięć w stosunku do tego, z czym mamy do czynienia obecnie. Celem poniższego tekstu jest jednak porządkujące nakreślenie kluczowego aspektu dzieła myśliciela, którego nazwisko z pewnościa nie zostało zapomniane. Przeciwnie, można zastanawiać się, czy jego intensywne przywoływanie w kontekście bieżących sporów politycznych lub też oceny działań podejmowanych przez republikańską administrację George'a W. Busha, podszyte zgoła nieśmiertelnym entuzjazmem dla „żydowskich” teorii spiskowych, nie powoduje wielkiej szkody, gdy idzie o uznanie potrzeby zrozumienia jednego z najgłębszych teoretyków (filozofów?) polityki, nie mówiąc o podjęciu ewentualnej polemiki z jego ustaleniami. Przy czym nie do utrzymania wydaje się pogląd, iżby najbardziej fundamentalne rozważania Mistrza, dotyczące tzw. problemu teologiczno-politycznego, były na tym samym poziomie i z jednakim wyczuciem tematu kontynuowane przez reprezentantów „szkoły” politologicznej (politologii jako „niesocjologicznej” bądź niepozytywistycznej nauki o polityce), która stworzył w powojennej Ameryce.

Nazwisko Leo Straussa - jako mrocznego wykładowcy sprzed pięciu dekad, będącego założycielem tajemniczej, hermetycznej i niewyobrażalnie wpływowej sekty straussistów, z której miał się wyłonić ruch polityczny zwany neokonserwatyzmem (Drury 1999: 137-178) - znalazło się na ustach mniej lub bardziej rzetelnych komentatorów w toku burzliwej debaty, jaka towarzyszyła recepcji za Oceanem najbardziej dramatycznych wydarzeń międzynarodowych ostatniego dziesięciolecia, czyli „Wojny z Terrorem” i przede wszystkim interwencji w Iraku. Debata ta (a w każdym razie potencjalnie istotny $\mathrm{w}$ niej watek Straussowskiego backgroundu strategii wojennej USA) pozostaje dla nas czymś odległym (Weinstein 2007: 238250). $Z$ jednej strony mamy więc nadmiar wypowiedzi (po angielsku), spośród których dokonanie selekcji może okazać się bardzo trudne, z drugiej - kłopot z wyjściową lokalizacją zagadnienia: czym jest „straussizm”? Co to znaczy - być „straussistą”? Gdyby te pojęcia rozciagnąc na wszystkich badaczy czy intelektualistów sympatyzujących z ustaleniami teoretycznymi Straussa albo po prostu zainspirowanych jego dorobkiem, to wówczas niewiele rozpoznalibyśmy z tego, co każe mówić o „szkole”. W przypadku

\footnotetext{
${ }^{1}$ Jak choćby Russell Kirk, z nieprzetłumaczonym na język polski dziełem The Conservative Mind, koronnym podsumowaniem anglosaskiego stylu myślenia o polityce na modłę arystokratyczno-zachowawcza, albo niemalże w ogóle nieznani w Polsce myśliciele katoliccy, np. Thomas Molnar czy Frederick Wilhelmsen.
} 
szkoły Straussowskiej mierzymy się bowiem ze świadomym projektem filozoficzno-politycznym opartym na wyjątkowo intensywnym przeżyciu relacji z Mistrzem.

\section{/// II}

Zważywszy na rolę samego „fundatora” szkoły, niepodobna uniknąć w tym miejscu krótkiego przypomnienia ścieżki intelektualnej, jaką podążył ów myśliciel. Leo Strauss rozpoczynał swą karierę akademicką - w Niemczech lat 20. - od zaangażowania w ruch syjonistyczny. Katastrofa kończąca żywot Republiki Weimarskiej w chwili, kiedy „kryzys teoretyczny” przerodził się w „kryzys praktyczny” (Gunnell 1987: 86), właściwie zbiega się z czasem największych odkryć Straussa, który dzieli odtąd los wielu żydowskich uciekinierów. Na emigracji zadaje coraz głębsze pytania o korzenie i sens nowoczesności (nowoczesnego ,ateizmu politycznego”); o prawomocność życia filozoficznego w świetle objawionego Prawa; o to, co łączy wszystkich filozofów niezależnie od partykularnych kontekstów ich ziemskiej egzystencji, co zarazem dzieli ich od ogółu współczesnych współobywateli czy współplemieńców, ostatecznie zaś czyni możliwym życie ludzkie w naturalnym dlań wymiarze partykularnej wspólnoty politycznej - wszystko to stanowi „problem teologiczno-polityczny”. Szkoła Straussa zostaje przez niego „wymyślona” również na emigracji.

Najistotniejszy okres działalności Straussa zaczyna się w chwili przyjęcia przez niego posady na University of Chicago w 1949 r. Wcześniej, podobnie jak wielu innych emigrantów, znalazł zatrudnienie w nowojorskiej New School for Social Research. Zaproszenie do Chicago dotyczyło pierwotnie wydziału filozofii; tam go jednakże nie zaakceptowano, ostatecznie więc trafił na wydział politologii (Butterworth: 6). Ośrodek chicagowski przeżywał wówczas wielki rozkwit, inicjujący utrwaloną po dziś dzień renomę w dziedzinie nauk społecznych. Błyskotliwie zarządzany przez Roberta M. Hutchinsa, stawał się przy tym, w odróżnieniu od uniwersytetów Ivy League, swoistym tyglem kulturowym (jedna z autorek piszących o szkole Straussowskiej przytacza warte zapamiętania, anegdotyczne stwierdzenie: „mówiono, że Chicago to miejsce, gdzie żydowscy profesorowie nauczają protestanckich studentów katolickiej filozofii’”) (Norton 2004: 202) ${ }^{2}$. Matecznik straussizmu był zarazem bastionem

\footnotetext{
${ }^{2}$ Autorka uzupełnia tę anegdotę następującym stwierdzeniem: „od wielu lat jest to miejsce, gdzie pogańską filozofię czyta się tak, jak Talmud, a katoliccy, żydowscy i protestanccy (teraz też hinduscy, muzułmańscy i buddyjscy) studenci nieśmiało liżą smarowany miodem tekst" (Norton 2004: 202).
} 
pozytywistycznie zorientowanych socjologów ${ }^{3}$, usposobionych, rzecz jasna, niechętnie wobec namiętnej lektury pism filozoficznych, na jakiej skupiał się Strauss (i zachęceni przezeń studenci). Owocujący wykształceniem pokaźniej liczby „politologów” - podczas gdy wydziały filozofii oraz filologii klasycznej nie dawały swoim studentom formalnej możliwości uczestnictwa w jego kursach - okres chicagowski Straussa trwał do roku 1967. Przygotowywane przezeń kursy (wykłady i seminaria) dotyczyły w mniej więcej równych proporcjach: myślicieli starożytnych (głównie Platona i Arystotelesa), myślicieli nowoczesnych (jak Machiavelli) oraz tematów przekrojowych („prawo naturalne”) (Anastaplo 1999: 4) ${ }^{4}$. Kwestie niemieszczące się w ramach oficjalnego nauczania „teorii politycznej”, dotyczące pism teologicznych czy literatury pięknej, były przez Straussa omawiane ze studentami na prywatnych spotkaniach (Rosen 2007: 150).

Trudno jest ujać w kilku słowach wrażenie, jakie ten oddany nauczyciel akademicki, doskonale świadom możliwości i ograniczeń swej roli ${ }^{5}$, mógł wywrzeć na młodych ludziach, nienawykłych do poważnego traktowania takich pojęć jak „dusza” czy „cnota”, nie mówiąc już o ezoterycznym przekazie filozofii ${ }^{6}$. Nie sposób jednak zaprzeczyć, że gdy idzie o zainteresowanie ich studiami nad kanonicznie ujmowanym dziedzictwem myśli politycznej, nad tradycja przypisana autorom „wielkich ksiag" (powiedzielibyśmy, tradycja politologii, która nie jest wynajdywana w wieku dwudziestym, lecz liczy sobie dwadzieścia kilka wieków), odniósł on niezaprzeczalny sukces dydaktyczny. Należy zarazem podkreślić, że „kanon” Straussowski różni się od tego, co prezentowały dawniejsze podręczniki: kluczowe miejsce zajmują w nim średniowieczni myśliciele niezwiązani z chrześcijańskim nurtem dziejów Zachodu, przede wszystkim - Majmonides i Al-Farabi ${ }^{7}$. Ten ostatni, piszący w X w. w Bagdadzie, stał się dla Straussa i jego uczniów wzorem filozoficznego komentatora, mającym do zaoferowania autentyczny „Sokratejski racjonalizm

\footnotetext{
${ }^{3}$ Za wymowny symbol tej orientacji może uchodzić napis zdobiący Social Science Research Building: ,jeśli nie możesz czegoś zmierzyć, to twoja wiedza jest mizerna i niezadowalająca” (Anastaplo 1999: 6).

${ }^{4}$ Pierwszy z tych kursów dotyczył myśli Rousseau, a uczestniczyło w nim zaledwie trzech studentów. Por. załącznik z listą zarejestrowanych wykładów i seminariów (Anastaplo 1999: 13-18).

${ }^{5}$ Por. wypowiedź Straussa w liście do Jakuba Kleina z 12 lipca 1949 r. (Strauss 2008: 597).

${ }^{6}$ Alfons Söllner pisze o „osobliwej dialektyce ezoterycznej formy i egzoterycznego wpływu, która stanowi zapewne tajemnicę sukcesu Leo Straussa. Zawiera się ona w prostym fakcie socjologicznym, iż - jako charyzmatyczny przedstawiciel teutońskiej uczoności w bardzo odmiennym środowisku amerykańskim - wiedział on, jak zebrać wokół siebie mniej lub bardziej oddaną wspólnotę «straussistów»" (Söllner 1997: 88).

${ }^{7}$ W tym kontekście por. opracowanie Straussa i Cropseya (Strauss, Cropsey 1963) z dziełem Sabine'a (Sabine 1961).
} 
polityczny" przeciwstawiany pochrześcijańskiemu, dogmatycznemu racjonalizmowi oświecenia (Pangle 1994: 12).

Jest ogromnie charakterystyczne, że uczniowie Straussa zwykli wypowiadać się o swoim Mistrzu z niebywała atencja. Wśród nich np. Harry Jaffa swoje spotkanie z przyszlym autorem Natural Right and History (jeszcze w czasach nowojorskich) porównuje do doświadczenia, jakiego zaznać miał biblijny Szaweł na drodze do Damaszku. ,Jestem przekonany - powiada Jaffa - że niczyje życie nie zostało tak zupełnie «obrócone» przez spotkanie ze Straussem, jak moje" (Jaffa 1999: 42). Z kolei Allan Bloom napisał w pośmiertnym peanie:

Strauss poświęcił się przywracaniu - bogatej i konkretnej - naturalnej świadomości zjawiska politycznego. Jego doprawdy zadziwiająca przejrzystość i świeżość w opisywaniu rzeczy dokoła nas pochodziła w znacznym stopniu ze sposobu, w jaki używał on starych ksiag, aby uwolnić się od wiążących nas kategorii $[. .$.$] Leo Strauss był filozofem. Nigdy nie powiedziałby tak o sobie,$ gdyż był za skromny i miał zbyt wiele szacunku dla tego rzadkiego typu ludzkiego - i dla drogi życia, jaka kryje się za tym określeniem - by przypisać sobie to miano, osobliwie w czasach, gdy używa się go tak tanio (Bloom 1991: 238-239) ${ }^{8}$.

Niezwykle sugestywne sformułowania podsuwa Werner Dannhauser, w obliczu ataków na swojego mentora podkreślający wprost dumę z bycia nazywanym „straussista”. Stwierdza wręcz: „on był centrum naszego intelektualnego i nawet naszego moralnego wszechświata. [...] Leo Strauss był jak słońce, wokół którego orbitować poczytywaliśmy sobie za przywilej" (Dahnhauser 1995: 4-5). Zajęcia ze Straussem cechować miały: prostota, radość życia, poczucie humoru oraz - co może być zaskakujące - ciagłe nawiązania do bohaterów kultury masowej, z którymi studenci obcowali na co dzień, do treści westernów itp. Przede wszystkim jednak Strauss

pokazał, że nasze opinie są zaledwie opiniami; sprawil, że zrozumieliśmy, że byliśmy ich więźniami, ukazując nam zarazem rozciagające się za nimi szersze horyzonty. Wszyscy wierzyliśmy - zwróćmy uwagę na to symptomatyczne wyznanie - w wyprane z mocy stwierdzenia wywiedzione od Marksa, Freuda i innych. Tymczasem u podstaw naszych poglądów tkwi myśl nowożytna [...] długo, ostro i błyskotliwie spieraliśmy się o kwestie, jakie wypływały podczas zajęć. Rozmawialiśmy, jedliśmy i piliśmy razem i do dziś większość moich

\footnotetext{
${ }^{8}$ Warto jednak zauważyć, że w swej najbardziej znanej książce, „konserwatywnym bestsellerze” The Closing of the American Mind, Bloom wspomina Straussa tylko raz, przelotnie, niemal skrycie. Por. w polskim przekładzie (Bloom 1997: 196).
} 
najbliższych znajomych to ludzie, którzy dzielili ze mną doświadczenie zajęć

Leo Straussa (Dannhauser 2007: 140, 142) ${ }^{\text {? }}$.

To doświadczenie wiązało się nade wszystko z prawdziwie wyzwolicielskim oddziaływaniem lektur - dzięki „,Straussowi, zamieniającemu dla nas książki we wszechświat" - odczytywanych w sposób możliwie najbardziej skrupulatny, „linijka po linijce”. W ten sposób jego uczniowie odkrywali, „że książka jest w istocie magiczną strukturą, że jest dosłownie pełna cudów". Dzieło filozoficzno-polityczne w oczach straussisty ,to dom o wielu skrzydłach, sekretnych pokojach i tajemnych przejściach". W obcowaniu z nim odtwarza się zdroworozsądkowy ogląd świata spraw ludzkich - niezapośredniczony przez żargon współczesnych nauk politycznych, niezniekształcony przez takie czy inne scjentystyczne uprzedzenia badaczy przekonanych o wyższości swoich narzędzi teoretycznych w stosunku do wiedzy, która nie opiera się na zastosowaniu metody naukowej. Według relacji Dannhausera,

nauczyliśmy się tego, co chyba najtrudniejsze: stać się na powrót odrobinę naiwnymi. Leo Strauss nauczył nas zaczynać od rozważenia problemu z punktu widzenia przeciętnego obywatela, choć zachęcał nas do pójścia dalej. Nauczyliśmy się na powrót doceniać przysłowia, nauczyliśmy się znów używać prostych słów. Zamiast o wartościach, mówiliśmy o dobru i złu; dyskutowaliśmy raczej o nieszczęściu niż o alienacji, rzeczy nie były już dysfunkcjonalne - po prostu nie działały (Dannhauser 2007: 142).

$Z$ jednej strony mamy więc odwołanie do naiwności, z drugiej - wskazanie na przekaz ukryty w ,wielkich księgach” (wydobywany metoda arcyuważnego komentatora z Bagdadu). O ile skojarzenie działalności Straussa jako nauczyciela akademickiego z głoszeniem jakiejś zamkniętej doktryny politycznej wydaje się nadużyciem, o tyle można pokusić się o twierdzenie, iż faktycznie z rozmysłem podjął on próbę odciągnięcia swoich studentów od ekspansywnych mód intelektualnych połowy XX w., uwrażliwiając ich na sposób, w jaki należy traktować zdroworozsądkowe opinie stanowiące podstawę życia politycznego, będąc jednocześnie świadomym dystansu, jaki dzieli je od wypowiedzi płynących z życia skupionego na poszukiwaniu mądrości. Tym samym filozoficzno-polityczne pytanie ,jak żyć?” znalazło się na powrót w centrum uwagi-z całym bagażem swego fundamentalnego znaczenia i subtelnej formuły; „zapomnienie o Byciu” okazało się czymś wtórnym wobec zapomnienia ludzkiej doskonałości. Jak to ujmuje Stanley Rosen, „,być może największym dokonaniem Straussa [...] było uodpornienie młodych ludzi na spekulatywne

\footnotetext{
${ }^{9}$ George Anastaplo pisze o żonach studentów Straussa, które „nie mogły już dłużej dzielić ze swoimi mężami najważniejszych spraw" (Anastaplo 1999: 6).
} 
ekscesy i hermeneutyczną brutalność Heideggera" (Rosen 2007: 153). Owi uodpornieni uczniowie wstępowali następnie na ścieżki własnych karier akademickich, odnajdując się na wydziałach nauk politycznych różnych uniwersytetów, skłonni przekazywać podejście Straussowskie kolejnym rocznikom studentów (angażującym się także w politykę). Sam Strauss w 1968 r. przeniósł się do Claremont Men's College, a rok później - do St. John College w Annapolis, gdzie poprowadził swoje ostatnie kursy: o Nietzschem i Prawach Platona (Anastaplo 1999: 18). Jego sytuacja tam nieco różniła się od tej z okresu chicagowskiego (nie tylko z racji późniejszego wieku i bardzo słabego zdrowia): „Strauss niekiedy wspominał, że odkąd jest w St. John's, nie musi tłumaczyć się, czy też przedstawiać uzasadnienia dla studiowania starych ksiag" (Berns, Braun 1999: 35). Do samego końca zajmował się wydobyciem politycznego (czy raczej teologiczno-politycznego) przesłania wielkich dzieł filozoficznych, gdy zaś umierał w 1973 r., mógł być w zasadzie pewny, że jego dzieło znajdzie oddanych kontynuatorów - na pewnym poziomie.

\section{/// III}

Jeśli uznać Straussa za myśliciela zmierzającego do stworzenia własnej szkoły filozoficznej, to należałoby zastanowić się nad możliwościa zidentyfikowania w ramach jego biografii aktu założycielskiego takiego przedsięwzięcia. Szybko nasuwająca się w tym względzie konstatację warto jednak poprzedzić kilkoma uwagami. Przede wszystkim, próżno doszukiwać się świadectwa tego, by zajmujący nas myśliciel próbował bezpośrednio wpływać na życie polityczne: Strauss spędzał swe życie wśród murów akademii, unikając „świateł sceny” (Strauss 1998: 277). Zdaniem Heinricha Meiera, „jedynym znaczacym aktem politycznym, do którego dokonania Strauss się zmusił, było założenie szkoły, ku czemu zyskał sposobność, gdy zaproponowano mu profesurę na politologii na University of Chicago w roku 1949. Co ważne, Strauss był na pewno świadom ceny, jaką musiał zapłacić za podjęcie tej politycznej decyzji” (ceny użycia własnych myśli przez niejednorodny krag następców). Z czego rodzą się dwa pytania: „co może popchnąć filozofa do założenia szkoły? I w jakim sensie owo założenie zawiera w sobie decyzję polityczną?” (Meier 2006: xviii). Co do pierwszej kwestii, to można wskazać na korzyści płynące z przedsięwzięcia - zarówno w aspekcie wewnętrznym, jak i zewnętrznym. W obrębie szkoły istnieje pewien porządek formułowania pytań i opracowywania możliwych odpowiedzi. W ten sposób może realizować się ambicja powołania do życia szczególnego forum dociekań intelektualnych 
w nierozpoznawanym wcześniej zakresie. Podjęta zostaje zarazem próba dźwignięcia odpowiedzialności, do jakiej filozof poczuwa się względem otoczenia, czyli zróżnicowanych w swym charakterze uczestników wspólnoty politycznej. Idąc za sformułowaniem Stanleya Rosena, „polityczna filozofia jest publicznym ukazywaniem się filozofii, albo, inaczej mówiąc, [...] filozofia nie może ukazywać się na scenie publicznej w niedostosowanej formie" (Rosen 1998: 146). Z jednej strony chodzi zatem o ugruntowanie dostępu do wypracowanego przez filozofa dorobku przez stworzenie pewnej tradycji nauczania, obejmującej kolejne pokolenia adeptów poruszanej dziedziny, z drugiej - o zapewnienie korzystnego obrazu filozofii w oczach niefilozofujących współobywateli; obrazu rodzącego szacunek i poparcie $z$ ich strony. Strauss jako nauczyciel zwrócił się nie tylko do tych, o których mógł sądzić, że uchwycą głębię jego własnych dociekań i będa je kontynuować na własną rękę. Pragnął również - wzorem Platona i Arystotelesa - dotrzeć do „dżentelmenów”, czyli osób kierujących się przede wszystkim poczuciem przywiązania do swego kraju, poruszonych (przynajmniej potencjalnie) chęcią działania na rzecz dobra wspólnego. „Jako obywatel Stanów Zjednoczonych Ameryki, był lojalny wobec kraju, który dostarczył mu schronienia przed prześladowaniem. Przedstawiał się jako przyjaciel liberalnej demokracji, która pozwalała mu wieść życie filozoficzne. Nakłaniał pewną liczbę swoich studentów do tego, aby badali historyczne, konstytucyjne i polityczne fundamenty Stanów Zjednoczonych - i zachęcał ich, by bronili tychże fundamentów. Szanował ich patriotyzm i uczył rozumienia powagi przypisanej życiu politycznemu". Jednocześnie, odtwarzając być może stosunek Sokratesa do Aten, „nie pozostawił on żadnej wattpliwości odnośnie do tego, że nie uznawał życia politycznego za najlepsze życie" (Meier 2006: XVIII-XIX). Polityczność decyzji Straussa można rozpatrywać zarówno z punktu widzenia pośredniego (i skądinąd wymykającego się w całości odgórnym kalkulacjom) wpływu jego nauczania na sferę dyskursu publicznego, jak i również przez sam fakt wewnętrznego zróżnicowania szkoły: znaleźli się w niej potencjalni filozofowie i potencjalni politycy, reprezentujący - w perspektywie Straussowskiej - odmienne czy wręcz rozłączne sposoby życia. Można sądzić, iż przekaz kierowany do nich był wewnętrznie zróżnicowany; podejmowali go w różny sposób, by następnie różnorako kierować go dalej (Benardete 2002: 45-46).

W takim kontekście ujawnia się jednakże niebezpieczeństwo wpisane w całe przedsięwzięcie: przerodzenia filozofii w sztywną doktrynę. Z dzieła o wielkiej złożoności wyłaniają się powtarzalne formuły, zdradzające swa 
użyteczność wobec szerzej zakrojonego kręgu odbiorców. Uczniowie uczniów Straussa mogą w końcu wkraczać na „powtarzalną trajektorię” poszukiwań intelektualnych (Lilla 2007: 138), dla których myśl Straussa staje się bardziej źródłem autorytetu aniżeli inspiracji. Co więcej, mamy dalej do czynienia z coraz ściślejszym powiązaniem zainicjowanej w ten sposób tradycji filozoficznej z sytuacją właściwą dla konkretnego ustroju: jeśli można tak ujmować straussizm, to należałoby go zapewne rozpatrywać jako część współczesnej amerykańskiej ideologii lub propagandy. Odkrycie filozoficznej treści łączyłoby się wówczas z odrzuceniem szerokich nawarstwień retorycznych. Problem dotyczy także tego, jak znajdywać ową treść, ważąc ustny i pisemny przekaz nauczyciela. W oczach zewnętrznego obserwatora podstawowym źródłem są starannie napisane książki. Wewnątrz szkoły ujawnia się natomiast tendencja do stawiania wyżej tego, co zostało usłyszane, a czego wage ze względów osobistych łatwo przecenić. Oddani słuchacze bronia spuścizny Mistrza przed niezależnie podejmowanymi próbami ukazania radykalizmu zawartego w jego myśleniu. Krótko mówiąc: szkoła rodzi postawy apologetyczne. „Strauss, jak nikt inny, zaznajomiony był z problemem szkoły i tradycji w filozofii" (Meier 2006: xx). Wnikliwie rozpatrywał losy nauk Platona, Arystotelesa, Epikura czy stoików, dazżąc do nakreślenia wyraźnej dystynkcji między filozofem a doktrynerem, intelektualistą a sekciarzem (Strauss 2009: 185; Strauss 2009: 185). „I właśnie dlatego, że znał historię szkół starożytnych, był także świadom tego, że tamte szkoły zasadniczo przyczyniły się do skierowania uwagi na filozofię jako drogę życia”. Ten klasyczny projekt można zestawić z wysiłkiem największych filozofów nowoczesności - Rousseau i Nietzschego - sławiących wielkość życia teoretycznego za pomoca własnych autobiografii ${ }^{10}$.

Alternatywę stanowiło założenie szkoły, z której nie muszą wychodzić jedynie należący do niej. Arystoteles należał do szkoły Platona przez dwadzieścia lat, niemal tak długo, jak długo zdołał nauczać w swojej własnej szkole Liceum. Arystoteles opuścił Akademię jako filozof, i następnie z jego szkoły wyłonili się inni filozofowie - tak, jak ze szkoły, którą założył Strauss, wyłonili się filozofowie - a w żadnym razie tylko „straussiści” (Meier 2006: XX).

Chcąc mocniej podkreślić zagadnienie sposobu partycypacji uczniów w dziele Mistrza, warto w tym miejscu wskazać swoisty „paradoks wyznawcy”: studenci dzielą się - z jednej strony - na tych, którzy w myśli filozofa odnajduja nade wszystko wyzwanie dla własnych dociekań oraz,

\footnotetext{
${ }^{10}$ Można wskazać, za Meierem, dwie kluczowe pozycje ilustrujące nowoczesne podejście do filozofii: J.J. Rousseau Marzenia samotnego wedrowca oraz F. Nietzschego Ecce homo: jak sie staje, caym sie jest.
} 
z drugiej strony, szczerze poruszonych dogmatyków; ci drudzy, jak powiada jeden z komentatorów, chcąc naśladować swego mentora, „stali się mu bliżsi na płytkim poziomie, podczas gdy oddalili się od niego na poziomie głębszym. Byli mu bliżsi, ponieważ ich idee bardziej przypominały Straussa niż te podejmowane przez uczniów Straussa" (tj. zainspirowanych potencjalnych filozofów). „Byli dalej od niego, ponieważ ich ideom brakowało głębi samego Straussa”. Jeśli po stronie „uczniów” znajdujemy skłonność do ożywczej refleksji, to z kolei „wyznawcy” zwykli wykazywać entuzjazm - pożyteczny, gdy idzie o trwanie i powodzenie przedsięwzięcia filozoficznego. W końcu ,wyznawcy prędzej ukażą polityczną siłę idei”: to w ich wydaniu subtelna myśl upraszcza się w doktrynę (Gilbert 2006: 117) ${ }^{11}$.

Reasumując powyższe kwestie, należy zwrócić uwagę, iż Straussowskie rozróżnienie między ezoterycznym (czyli kierowanym do „rozumnych przyjaciół" bądź potencjalnych następców na drodze filozofowania) a egzoterycznym (czyli adresowanym do publiczności, formującej otoczenie tyleż niejednorodne, ile skłonne do jednoczesnego utożsamiania się z pewnym zestawem kluczowych wierzeń, mniemań, opinii) nauczaniem filozofa (Strauss 1998: 107-121) zdaje się doskonale wpisywać w jego projekt szkoły filozoficznej. Mająca swoje źródło w teologiczno-politycznych rozważaniach Straussa, byłaby to szkoła myślenia politycznego w niejako podwójnym sensie: po pierwsze - nauczania potencjalnych filozofów właściwych relacji ze wspólnotą polityczną („,publicznego ukazywania się filozofii”); po drugie - nauczania potencjalnych polityków (czy też nauczycieli polityki), „wyznawców”, odpowiedzialnego - zatem: z pożytkiem dla filozofujących - kierowania sprawami wspólnoty politycznej, stwarzającej takie czy inne warunki życia, w tym - życia teoretycznego, vita contemplativa.

\footnotetext{
${ }^{11}$ Interesujące rozróżnienie na „uczniów Straussa” i „straussistów” nie oznacza, rzecz jasna, wskazania wyraźnej granicy między konkretnymi typami ludzkimi, tak, iżby można było zyskać pewność w przypisywaniu do nich poszczególnych osób czy środowisk. Wypowiadając się na temat „uczniów Straussa”, stwierdza Barry Gilbert: „nie mam na myśli po prostu tych, którzy byli z nim niegdyś na sali wykładowej. Mam raczej na myśli tych, którzy byli z nim na sali, a którzy odkryli coś ważnego do nauczenia się od niego, którzy uznali go za nauczyciela w najlepszym sensie tego słowa. Prawdziwym uczniom idee Straussa oferowały wyzwanie [...]. Niektóre z idei Straussa stały się ich własnymi, ale dopiero po tym, gdy poradzili sobie z dopasowaniem tych idei do całości własnego myślenia [...] w przeciwieństwie do tego, straussiści są mniej refleksyjni. Istnieją kluczowe elementy w myśli Straussa, które zaakceptowali oni dogmatycznie [...]. W odniesieniu do «paradoksu wyznawcy» okazuje się, że czasami nie jest łatwo powiedzieć, czy ktoś jest prawdziwym uczniem, czy wyznawcą. Ci, których nazwałbym straussistami lub wyznawcami Straussa, zapewne nie widzieliby sami siebie w ten sposób. Przeciwnie: stosując moje rozróżnienie, nazwaliby siebie uczniami Straussa” (Gilbert 2006: 116-117).
} 


\section{/// IV}

Powróćmy na chwilę do zasugerowanego wcześniej pytania o konkretny „akt założycielski” szkoły Straussa (by nie powiedzieć, oficjalny „zapłon” ruchu intelektualnego zwanego straussizmem). W tym kontekście nasuwa się właściwie jedna publikacja książkowa, a mianowicie Natural Right and History. Jak stwierdza Mark Lilla,

książkę tę, która spośród jego dzieł wywarła największy wpływ, należy postrzegać jako dokument założycielski szkoły straussowskiej. Stanowiła ona, by tak rzec, podanie Straussa o obywatelstwo i jego sposób przyjęcia akademickiej posady w dziedzinie politologii (Lilla 2007: 136).

Mowa tu o wydanym w 1953 r. zbiorze sześciu chicagowskich wykładów, podejmujących w całości zagadnienie uniwersalnego kryterium sprawiedliwości, jakie mogłoby zostać odkryte dzięki samodzielnemu rozpoznaniu przez ludzki rozum naturalnych podstaw życia politycznego. Punkt wyjścia do opisu najważniejszych historycznych ujęć tego problemu stanowi dramatyczne ukazanie zagrożenia wynikającego z negacji norm prawnonaturalnych w łonie XX-wiecznych nauk politycznych czy społecznych. Wszelkie rozważania z zakresu historii idei zostaja jednak poprzedzone emfatycznym wprowadzeniem, odwołującym się wprost do uczuć amerykańskiego czytelnika. „Prawo naturalne” okazuje się więc nade wszystko przedmiotem politycznej wiary; wiary, na jakiej opiera się sens i powaga zamysłu ustrojowego Stanów Zjednoczonych.

Zaproponowanie wyraźnej opozycji względem nurtu dominującego w powojennych naukach społecznych, w szczególny sposób podbudowane wykładami na temat ezoteryzmu (szerzej zaś - ahistorycznej, niezapośredniczonej lektury „ksiag”), powodowało z jednej strony negatywną reakcję przedstawicieli uniwersyteckiego establishmentu (by nie rzec: pogardliwą niechęć i dążenie do izolacji Straussa), z drugiej jednak mogło wzbudzić intensywne zainteresowanie u młodych adeptów politologii, którym autor Persecution and the Art of Writing jawił się jako ktoś w rodzaju osamotnionego mędrca ${ }^{12}$, człowieka zagadkowego, delikatnego i całkowicie

\footnotetext{
${ }^{12}$ Świadectwo tego rodzaju ambiwalencji w odbiorze dokonań Straussa przekazuje on sam w polemicznej (i w gruncie rzeczy prześmiewczej) odpowiedzi na tyleż krytyczne, ile rzadkie recenzje książki Persecution and the Art of Writing. Stwierdza tam m.in.: „ostatnio pewien student na University of Chicago powiedział mi, że sugestia, jaką poczyniłem zarówno na sali wykładowej, jak i w publikacji książkowej, okazała się budzić zainteresowanie niektórych spośród jego przyjaciół, jednak nie jest dla nich wystarczająco jasna [...]. Sadzę, że takie obiekcje wyrastają z trudności podobnych do tych, które odczuli rozmaici studenci [...]. Moi młodzi przyjaciele oczekiwali przeto, iż wspomniana sugestia wzbudzi pewne zainteresowanie w kręgach badaczy. Jednak młodzi ludzie nie znają się na tego rodzaju sprawach. Zainteresowało się tylko czterech czy pięciu badaczy z mojego pokolenia" (Strauss 1954: 64-65).
} 
oderwanego od spraw przyziemnych (Benardete 2002: 37; Anastaplo 1999: 3-12, Arkes 1999: 69). W ciagu kilkunastu lat pracy na chicagowskim uniwersytecie Strauss skupił wokół siebie dość liczne grono oddanych studentów, pojmujących swą przynależność środowiskowa (tj. uczestnictwo w formalnych i nieformalnych spotkaniach $z$ Mistrzem oraz we własnym gronie) jako udział w niezwykle ważnym przedsięwzięciu odnowy klasycznej filozofii politycznej czy też systematycznej refleksji na temat spraw ludzkich, nieciążącej w stronę scjentystycznego modelu naukowości, a wręcz odwołującej się do przeciwstawienia problematycznym (gdyż mogacym lec u podstaw politycznego czy moralnego zła) osiagnięciom nowoczesnych naukowców czy inżynierów rozważnej, sceptycznej mądrości dawnych filozofów. Wyłaniał się stąd wysiłek oddzielenia nauki o polityce od nauki konstruowanej na bazie modelu wypracowanego wcześniej na potrzeby przyrodoznawstwa, modelu podlegającego krytycznej ocenie, gdyż utkanego z oświeceniowej wiary w postęp i zarazem podatnego na ciosy ze strony współczesnych wrogów racjonalizmu. Jak stwierdzał Joseph Cropsey (Festschrift z 1964 r.),

dzieło prof. Straussa w ramach filozofii politycznej zachęcało ludzi do tego, by ponownie rozważyli przeważające mniemanie, które umieszcza środek ciężkości w naukach przyrodniczych i matematyce (Cropsey 1964: ix).

Jednym z pierwszych wspólnie wypracowanych owoców pobudzonej w ten sposób refleksji był wydany jeszcze w 1962 r. zbiór krytycznych esejów poświęconych różnym podejściom badawczym w ramach ówczesnego dyskursu politologicznego, przygotowanych przez uczniów Straussa (Storing 1962), do którego on sam napisał słynny Epilogue piętnujący nowoczesne nauki społeczne (których ostateczny fundament stanowi nic innego, jak tylko dogmatycznie przyjmowany ateizm) w imię zdroworozsądkowej nauki Arystotelesowskiej. Jest przy tym znamienne, że tekst nauczyciela znacznie przerósł $\mathrm{w}$ swym polemicznym tonie - by nie rzec: całościowej, bezkompromisowej negacji nowoczesnej nauki o polityce wypowiedzi młodych (wówczas) straussistów. Jak zauważa Nasser Behnegar, nieprzychylny odbiór tego wystapienia

zapewne jeszcze bardziej utrudnił uczniom Straussa otrzymanie posad na wielu wydziałach politologii, jak również wzmocnił opór wobec niego na jego własnym wydziale, opór, który ostatecznie zmusił Straussa do opuszczenia University of Chicago (Behnegar 2003: 142).

Można uznać, że była to lekcja swoistej bezkompromisowości w wyrażaniu własnych poglądów czy też sposobów ujmowania rozpatrywanych zagadnień. 
Jednak najbardziej dojmujące doświadczenie formacyjne rodzącego się środowiska szkoły Straussowskiej, przede wszystkim jeśli wziąć pod uwage stopniową afiliację tegoż lub nawet częściowe utożsamienie z intelektualnym zapleczem neokonserwatyzmu, stanowiły niewatpliwie wydarzenia lat 60., obejmujące ekscesy akademickiej kontrkultury na tle ogólnej radykalizacji dyskursu publicznego. Doświadczenie to zostało w szczególnie dojmującym stylu wyrażone przez Allana Blooma w jego Umyśle zamknietym, w którym bieżącą diagnozę kryzysu kształcenia uniwersyteckiego (choć wskazująca korzenie tego kryzysu na poziomie historii idei odczytywanej zadziwiająco wiernie w perspektywie Straussowskiej) wywodzi się zasadniczo z przemian politycznych i obyczajowych zainicjowanych w tym właśnie momencie dziejów amerykańskiego społeczeństwa (Bloom 1997: 373-400) ${ }^{13}$. Właściwe określenie charakteru owych zjawisk zawiera się jednakże w stanowisku samego Straussa. Stanowisko to wiąże się przede wszystkim z pamięcia o losach Republiki Weimarskiej, ze wspomnieniem słabości i upadku liberalno-demokratycznego ustroju konstytucyjnego, który nie doczekał się obrony ze strony najpoważniejszych sił politycznych, ale także intelektualnych, w ówczesnych Niemczech (Strauss 1989: 224-226, Strauss 1998: 78). W związku z wyraźnym eksponowaniem tych wątków można mówić o nauczaniu lojalności wobec (przyzwoitej) konstytucji ${ }^{14}$. Jak stwierdza Stephen Smith, ,jako instytucjonalista, Strauss uczył swoich czytelników poważnego traktowania konstytucji, nade wszystko struktury zawartych w niej uprawnień i odpowiedzialności. Martwiła go tendencja współczesnych nauk politycznych do tego, by lekceważyć konstytucyjne formalności przez skupienie się na masowych zachowaniach czy - jak to jest nazywane dzisiaj - problemach działań zbiorowych". Rozpoznany przezeń na przykładzie ustroju weimarskiego ,atak na konstytucjonalizm uwidocznił się w latach 60., kiedy radykałowie dyskredytowali rządy przedstawicielskie i «sprawiedliwość proceduralną» w imię bezpośredniej demokracji uczestniczącej”. Współczesny komentator dzieła Straussa dodaje:

ostatnie propozycje bardziej deliberatywnej formy demokracji oraz żądania publicznie finansowanych dni narodowej deliberacji stanowia jedynie

\footnotetext{
${ }^{13}$ Por. krytyczne uwagi Anne Norton (Norton 2004: 57-73). Autorka jednoznacznie piętnuje nastawienie Blooma, wynikające ze wskazanych doświadczeń, stwierdzając wręcz, iż „Bloom podejmuje język antysemityzmu - dawne oszczerstwa, stare resentymenty - by przekierować go od Żydów w stronę czarnych" (Norton 2004: 72). Zob. też Dannhauser 1995: 11-12. Por. Kinzel 2002: 31-38.

${ }^{14}$ Strauss odwoływał się do klasycznego pojmowania mądrości jako nierozdzielnej od umiarkowania, powiadając o tym, iż „mądrość wymaga nie znającej wahań lojalności wobec przyzwoitej konstytucji, a nawet wobec samego konstytucjonalizmu" (Strauss 1998: 276).
} 
rozwodnione wersje populistycznego najazdu na Konstytucję (Smith 2006: 182) ${ }^{15}$.

W kontekście wywołanych tym napięć szkoła Straussowska jawiłaby się jako środowisko obrońców tego, co można nazwać duchem republikanizmu a contra nadużyć teoretyków demokracji; lub inaczej: specyficznie związany intelektualny nurt strażników praw stanowiących fundament ustroju republikańskiego bądź też ładu instytucjonalnego określającego sposób życia w ramach partykularnej wspólnoty politycznej, jaką są Stany Zjednoczone Ameryki.

\section{// V}

Zjawisko intelektualne straussizmu łączy się, jak widzieliśmy, ze wskazywaniem potrzeby naiwnej czy też zdroworozsądkowej (odrzucającej zatem dążenie do historycznego ukontekstowienia na rzecz wyobrażenia stałej, „,naturalnej” dysputy wokół kluczowych problemów życia politycznego) interpretacji tekstów albo wypowiedzi (przemówień itp.) mających walor polityczny. Kontestując zakrycie zdroworozsądkowego szczegółu przez „naukową" czy „historyczną” abstrakcję - co w praktyce może oznaczać lekceważenie wszelkich ustaleń komentatorów „z zewnątrz” - uczniowie Straussa „często zdają się wyróżniać swoim brakiem wiedzy na temat przestudiowanych przez siebie książek, wiedzy posiadanej przez każdego drugoroczniaka" (Tarcov 1983: 22). Tworzą oni więc niejako odrębny dyskurs w ramach politologii, w dziale historii myśli politycznej. Możemy również zauważyć, że przyjęty w szkole Straussowskiej podstawowy sposób odczytania klasycznych dzieł filozoficznopolitycznych (oraz tekstów poetyckich) zdecydowanie dowartościowuje to, co w jezzyku Mistrza tworzy poziom „naturalnej jaskini” (Strauss 1997: 439): zwyczaj, opinię, a nade wszystko prawo (Benardete 2002: IX). Towarzyszy temu wiedza o zasadniczym przeświadczeniu Straussa, iż jakkolwiek działanie filozofa może wpływać na kształt czy jakość wierzeń, na jakich opiera się dane społeczeństwo, nie jest możliwe zastapienie tych wierzeń (bądź wiary w autorytet Prawa czy praw) przez uniwersalnie ważną i powszechnie dzieloną mądrość wywodząca się z dociekań rozumowych; filozof nie jest prawodawca, lecz raczej sceptykiem podejmującym wysiłek zrozumienia racjonalności Prawa (jako podstawy tego, co politycznie istotne, źródła powagi i sensu) i uprawomocnienia własnej drogi życia; filozofia ma

\footnotetext{
${ }^{15}$ Por. wywody Harveya Mansfielda w kontekście obrony (nauki o) konstytucji (Mansfield 1991: 137162, 1978: 16 i n.).
} 
charakter „zetetyczny” (Strauss 2009: 185), tzn. skupia się na otwartych zagadnieniach i nie wytwarza pewności w odbiorze tego, co jest.

Rozpatrując kwestię radzenia sobie $\mathrm{z}$ tak zarysowanym poglądem na temat relacji filozofia - prawo, rozpoznajemy podłoże nieuchronnych, głębokich napięć pomiędzy straussistami. Innymi słowy: mamy do czynienia $\mathrm{z}$ fundamentalnym watpieniem $\mathrm{w}$ powodzenie projektu oświecenia, co z kolei niesie ze sobą uznanie nieprzekraczalnej różnorodności partykularnych sposobów życia ludzi, mających jednak pretensje do wyłączności. Należy zatem traktować poważnie różne stanowiska czy perspektywy wskazujące oddzielne wizje dobra. Jak zauważa Gregory Bruce Smith, dla samego Straussa „było to czymś koniecznym, że istnieja wierzacy, prawodawcy, patrioci, myśliciele rozmaitej barwy i miary i tak dalej” (Smith 1999: 121). Można się natomiast zastanawiać, czy jego punkt widzenia - zdolny wziąć pod uwagę szczególne pretensje religii objawionej bądź raczej objawionego Prawa - mógł zostać utrzymany jako cecha namysłu teoretycznego jego uczniów i „wyznawców”, czyniących dzieło swojego Mistrza zrozumiałym dla siebie i własnych studentów. Dzieło to z pewnością stanowi dla nich rodzaj planu orientacyjnego w dziedzinie historii myśli politycznej i zarazem niedościgniony wzór dogłębnego opisu wybranych postaci czy zagadnień. Znakomita ilustracja związanego z tym ciężaru intelektualnego wydają się słowa Harveya Mansfielda odnoszące się do Thoughts on Machiavelli:

studiując Machiavellego, za każdym razem, gdy byłem wyrzucany na niezamieszkałą wyspę, o której sądziłem, że nie została zbadana, napotykałem maleńki znak mówiący „proszę zostawić monetę”. Po tym, jak to robię, obszerny znak rozbłyska neonowym światłem widocznym z daleka, z takim oto przesłaniem: Leo Strauss był tutaj (Mansfield 1996: 219).

Istotnie, uczniowie Straussa, podążywszy - jak zostało wcześniej powiedziane - nader przewidywalnymi ścieżkami eksploracji pewnej puli tematów, niechybnie dostarczaja świadectwa zależności własnych ustaleń od ustaleń założyciela szkoły. Czy jednak w ogóle pojmują oni właściwą płaszczyznę (teologiczno-polityczna) rozważań autora On Tyranny? Czy ich „zwrot ku Ameryce” oznacza rezygnację z głębi?

\section{/// VI}

Zgodnie $\mathrm{z}$ twierdzeniem samego Straussa, namysł nad problemem teologiczno-politycznym określa całość jego dorobku. Jeśli tak jest, to znana periodyzacja tegoż, autorstwa Allana Blooma - wyodrębniającego 
w dziele Mistrza trzy „fazy rozwoju” ${ }^{16}$ - okazuje się, przynajmniej pod pewnym względem, nieco myląca; problem wzajemnej relacji Prawa i filozofii, z czasem być może ujmowany z coraz większą dozą skupienia i tajemniczości, wydaje się być obecny i porównywalnie wyrażany we wszystkich tekstach Straussa ${ }^{17}$, odzwierciedlając wciąż na nowo jego pierwotną intencję odpowiedniego uchwycenia własnego położenia człowieka niejako podwójnie odróżnionego od ogółu obywateli nowoczesnego państwa (outsidera czy wygnańca w sensie zarówno politycznym, jak i filozoficznym). Zasadniczy problem, przed jakim stanął młody Strauss stwierdzający klęskę nowoczesnego czy oświeceniowego racjonalizmu w jego próbie oddalenia roszczeń tego, co objawione, został przez niego samego wyrażony po upływie kilkudziesięciu lat w następujący sposób:

zwycięstwo ortodoksji przez samozniszczenie racjonalnej filozofii nie stanowiło absolutnego błogosławieństwa, gdyż było to zwycięstwo nie żydowskiej ortodoksji, lecz jakiejkolwiek ortodoksji, a żydowska ortodoksja od początku opiera swoja pretensję do wyższości nad innymi religiami na swej wyższej racjonalności (Strauss 1989: 256) ${ }^{18}$.

Czy jest możliwe racjonalne potraktowanie judaizmu - religii, bez której nie może istnieć naród żydowski - i wskazanie jego przewagi nad roszczeniami płynącymi z innych wierzeń, religii bądź ideologii? Właściwe

\footnotetext{
${ }^{16} \mathrm{~W}$ ujęciu Blooma - podkreślającego wszakże ciagłość opisywanego rozwoju - pierwsza faza ma charakter „pre-Straussowski” i obejmuje teksty Straussa pisane po niemiecku, które wciąż „podlegają nowoczesnym kanonom badawczym z ich historycznymi przesłankami. Książki te przedkładają autorom [Spinozie, Majmonidesowi, Hobbesowi] własne pytania Straussa; nie nauczył się on jeszcze widzieć ich pytań tak, jak widzieli je oni sami”. Wczesny Strauss „nie zna jeszcze starożytności”. Z kolei „drugą fazę zdominowało odkrycie pisania egzoterycznego, które jest [...] tożsame z odkryciem starożytności, a stąd rzeczywistej alternatywy". Do tego okresu należą: Persecution and the Art of Writing, On Tyranny i Natural Right and History, przy czym ta ostatnia zawiera „syntezę zainteresowań Straussa oraz niehistoryczną historię filozofii. Wreszcie trzecią fazę charakteryzuje kompletne porzucenie zarówno formy, jak i treści nowoczesnych badań. Strauss nie czuł się dłużej zobowiązany do tego, by czynić jakiekolwiek kompromisy czy też oglądać teksty przez sito uczonej metody i kategorii. Wyzwolił się i mógł rozumieć piszących tak, jak oni siebie rozumieli. Rozmawiał z nimi tak, jak można by rozmawiać z mądrym i subtelnym współczesnym o naturze rzeczy”. Bloom dodaje: ,pisma Straussa z pierwszego okresu były traktowane z szacunkiem, jako uczone wytwory człowieka o nieco ekscentrycznych zainteresowaniach. Te z drugiego uznano za perwersyjne, wzbudzały one gniew. Te z trzeciego okresu zostały zignorowane" (Bloom 1991: 246-247, 249). Należy zaznaczyć, że to porządkujące ujęcie stanowi część hagiograficznego tekstu pisanego wkrótce po śmierci Mistrza.

${ }^{17}$ Pewne potwierdzenie tej konstatacji można znaleźć w prywatnych listach Straussa. Np. 25 lutego 1951 r. pisze on do Erica Voegelina: ,jeśli chodzi o Philosophy and Law, to jestem przekonany, że zasadniczo stoję wciąż na tym samym gruncie. Oczywiście, mam nadzieję, że w ciagu ostatnich piętnastu lat pogłębiłem swoje nauczanie, przez co wiele spraw wyraziłbym inaczej” (Emberley, Cooper 2004: 78). ${ }^{18}$ Strauss wskazuje w tym miejscu na cytat z Księgi Powtórzonego Prawa $(4,6)$ : „strzeżcie i wypełniajcie je [tj. prawa i nakazy od Boga przekazane Jego ludowi], bo one są waszą mądrością i umiejętnością w oczach narodów, które usłyszawszy o tych prawach, powiedzą: «Z pewnością ten wielki naród to lud mądry i rozumny»" (Pismo Święte Starego i Nowego Testamentu [Biblia Tysiąclecia], przeł. zespół biblistów polskich z inicjatywy benedyktynów tynieckich, Poznań-Warszawa 1980, s. 177).
} 
dla Straussa ujęcie problemu teologiczno-politycznego sadowiące to, co boskie, na planie koniecznych (rozumnych) regulacji życia wspólnoty, opiera się na przyznaniu, iż nie istnieje rozwiązanie „ostateczne” czy uniwersalne (Strauss 1989: 230); jednak w takim wypadku kluczem do zrozumienia stanowiska tego myśliciela okazuje się właściwe rozumienie factum brutum objawienia (stanowi ono poniekąd zdarzenie historyczne i przez to wydaje się uderzać w sam fundament ponadhistorycznych aspiracji Sokratejskiego filozofa [Tanguay 2007: 212]; droga do Greków prowadzi przez myśl średniowieczną, skumulowaną nade wszystko w dziele Al-Farabiego - myśl konfrontującą się z objawieniem) jako objawionego Prawa, niejako pociagające za sobą właściwe rozumienie filozofii.

Otóż uczniowie Straussa zasadniczo różnią się w swoim ujęciu religii czy objawienia, a różnica ta łączy się z postrzeganiem przez nich relacji między nauczaniem egzoterycznym a ezoterycznym. Z jednej strony mamy zatem do czynienia z wyraźnym stanowiskiem Thomasa Pangle’a, który przynajmniej na pewnym etapie swoich dociekań - zdaje się sprowadzać sens tego, co objawione, do sfery poetyckiej, formującej następnie zewnętrzny, „obronny” przekaz filozofa. Jego zdaniem, w ramach interpretacji zaproponowanej przez Straussa „to, co najbardziej istotne w sporze między Platonem a Biblia, jest już obecne w sporze między Platonem a poetami” (Pangle 1989: 20). Wszelkie odwołanie do Biblii (czy raczej moralności biblijnej) na planie politycznym oznaczałoby w takim razie nic więcej, jak tylko zastosowanie „szlachetnego kłamstwa” czy też próbę zakrycia nihilistycznych rezultatów filozofowania. Jak słusznie zauważa Susan Orr, preferencja na rzecz Boga żydów lub chrześcijan raczej, aniżeli któregoś z bóstw panteonu greckiego, nie wykracza tutaj poza kwestię ,smaku” (Orr 1996: 26). Z drugiej strony znajdujemy pogląd reprezentowany głównie przez Harry'ego Jaffę i jego zwolenników, odżegnujących się od jakiegokolwiek skojarzenia dzieła Straussa z „,przebranym” nihilizmem; ich zdaniem Straussowski opis nowoczesności nie może być wikłany w obraz podwójnego nauczania; nie istnieje tajemny przekaz zawierający rzekomo odkrycie braku uzasadnienia dla prawych działań czy cnoty moralnej ${ }^{19}$.

W jednym ze swoich tekstów Jaffa odwołuje się do zadziwiająco ustylizowanego początkowego fragmentu książki Straussa The City and Man, mówiącego o „boskim przesłaniu” miasta „Prawości” i „Wiary”

\footnotetext{
${ }^{19} \mathrm{~W}$ polemicznym ujęciu Jaffy „odrębność Straussa - w istocie, pomyślałbym, jego wyjątkowość tkwiła nade wszystko w tym, że był on pierwszym wielkim krytykiem nowoczesności, którego diagnoza dolegliwości nowoczesności nie kończyła się szukaniem rozwiązania dla tych dolegliwości poprzez radykalizację zasad nowoczesności” (Jaffa; dostęp: 7 października 2011 r.).
} 
i „posłuszeństwie wobec niego” jako swego rodzaju dictum rozpoznawanym przez filozofa politycznego (Strauss 2008: 164):

tym, co najbardziej znaczące [...] jest to, iż Miasto, którego konturów poszukuje człowiek zdany na siebie ze swoimi zdolnościami i które chcemy zrozumieć w sposób tak pełny, jak to po ludzku możliwe, jest Miastem Wiary. Jerozolima i Ateny zdaja się stawać jednym i tym samym (Jaffa 1999: 47).

Można zatem sądzić, że ustalenia samodzielnie (bez Bożej pomocy) dociekającego rozumu indywiduum nie tyle doprowadzą do uświadomienia sobie ograniczeń w użyciu rozumu (z czego u Straussa wynika „zetetyczna” koncepcja filozofowania), ile staną się możliwie pełna, racjonalna, filozoficznie dyskursywną $\mathrm{i}$ w miarę harmonijna podbudowa tego, co objawione. Jest to, jak się wydaje, moment kluczowego napięcia między „oryginalnym” straussizmem i straussizmem Jaffy (Batnitzky 2006: 236). Z kolei trudność wynikająca z całkowicie instrumentalnego potraktowania objawienia, czyli utrzymania jedynie „ateńskiej” perspektywy osądu spraw ludzkich (dobre jest to, co sprzyja erotycznym dążeniom filozofów), prowadzi do nostalgicznego opiewania poniekąd próżnej estetyki vita contemplativa, co wyraźnie uwidocznia się w tekstach Blooma.

\section{/// VII}

Pragnąc przedstawić jedynie zarys zbiorowego portretu szkoły Straussowskiej, należy zastanowić się nad uporządkowaniem - z konieczności nieoddającym w pełni intelektualnej złożoności zjawiska, ale pożytecznym z uwagi na brak jakichkolwiek tego rodzaju ustaleń w polskiej literaturze przedmiotu - głównych nurtów straussizmu. W tym miejscu wypada znów zauważyć, że spuścizna Straussa w sposób mniej lub bardziej dosłowny inspiruje wielu myślicieli, pisarzy i intelektualistów, z pewnościa nieuznających siebie za reprezentantów myślenia Straussowskiego, a tylko utwierdzonych we własnych pogląach czy obserwacjach przez recepcję tego sposobu myślenia. Do takich postaci - zdradzających intelektualne powinowactwo ze straussizmem - należa m.in.: Willmoore Kendall, George Grant, Emil Fackenheim czy Saul Bellow. Ten ostatni, pisarz-noblista będący jednocześnie przyjacielem i uniwersyteckim kolegą Allana Blooma w Chicago, dokonał wprowadzenia wątków Straussowskich do współczesnej literatury pięknej. W napisanym przez niego dla uczczenia zmarłego wcześniej Blooma Ravelsteinie pojawia się postać „profesora Davarra" jako literackie alter ego Straussa:

Ravelstein [Bloom] był wychowankiem, albo jeśli wolicie uczniem, Davarra. Podejrzewam, że mogliście nie słyszeć o tym zdumiewającym filozofie. Jego wyznawcy mówia, że był to filozof w klasycznym sensie tego słowa [...]. Przed 
laty spotykałem czasem Davarra na ulicy i trudno mi było sobie wyobrazić, że ta drobna, oderwana od rzeczywistości postać w okularach była demonicznym heretykiem znienawidzonym w całych Stanach Zjednoczonych, a nawet poza ich granicami (Bellow 2001: 113).

Bellow wyraża w sposób bardzo sugestywny zasadniczy charakter Straussowskiej diagnozy nowoczesności jako życia w środowisku sztucznej kreacji nazw, pojęć czy opisów rzeczy. Otóż

pod rumowiskiem nowoczesnych idei pogrzebany był świat, który należało dopiero odkryć. Jego zdaniem [Ravelsteina-Blooma] szara sieć abstrakcji, jaka przykryto świat w celu jego symplifikacji i interpretacji zgodnej z naszymi kulturalnymi celami, uchodziła w naszych czasach za świat rzeczywisty. Potrzebowaliśmy alternatywnej wizji, zróżnicowania poglądów - przy czym miał tu na myśli poglądy nie zdominowane przez ideologię. Problem tkwił, jego zdaniem, w słownictwie (Bellow 2001: 217).

To charakterystyczne ujęcie można skojarzyć z zaproponowanym przez młodego Straussa obrazem „drugiej jaskini” (nowoczesnej, ,nienaturalnej”), z której poziomu droga do jaskini Platońskiej wiedzie przez przywrócenie zdroworozsądkowego oglądu rzeczywistości ${ }^{20}$.

Stwierdzenie wspólnej podstawy intelektualnej czy dzielonego impulsu do rozważań nie może przysłaniać różnorodności podejść rozwijanych (w obu wymiarach „podwójnego nauczania”) przez uczniów Straussa. W ciagu ponad półwiecza od swego „ufundowania” Straussowska szkoła myślenia o polityce skupiała wielu uczonych (jak i doktrynerów czy „wyznawców”) koncentrujących się na rozpoznaniu wielości biegunów narracji historycznofilozoficznej, jakie odnajdywano w dziele Mistrza, intelektualnych akolitów wytrwale zdobywających przyczółki w ramach życia akademickiego i debaty publicznej (przy czym należałoby zaznaczyć, że w tym szerokim gronie mieszczą się filozofowie i badacze filozofii, jak Stanley Rosen czy Seth Benardete, których dorobku - jakkolwiek oddziałującego na resztę - z pewnością nie należy wiązać wprost z wysiłkiem tworzenia teoretycznej podstawy wpływów politycznych). Ernest Fortin, posuwajacy się do skojarzenia ograniczeń czy oporu napotykanego przez straussistów z prześladowaniami w początkach chrześcijaństwa,

\footnotetext{
${ }^{20}$ Diagnoza nowoczesności rozwijana przez Bellowa - będąca ujęciem niewațliwie zasługującym na uwagę badacza myśli politycznej - zdradza inspiracje stanowiskiem Straussowskim, ale także pogladami Kojève'a; pod tym względem wydaje się zasadniczo paralelna do myśli Blooma, która zostanie przedstawiona w następnym podrozdziale. W tym ujęciu „cele rewolucji leninowskiej [dążącej do urzeczywistnienia „pierwszych zasad nowoczesności”] nie zostały zrealizowane w Rosji, lecz spełniły się w burżuazyjnej Ameryce, mówi filozof Kojève. Przy okazji jednak rozpłynęło się wszystko, dla czego warto żyć” (Bellow 1998: 126). Bellow stwierdza niemal za Bloomem (i Straussem): „,musimy powrócić do Biblii, Platona, Shakespeare’a, aby się przekonać, kim był kiedyś człowiek" (Bellow 1998: 167). Por. tegoż Rozproszenie unvagi (Bellow 1998: 169-194).
} 
proponuje multum określeń dla różnych odłamów „ruchu”, do którego sam się zalicza jako „Straussowski teolog”; pisze m.in. o: „straussistach filozoficznych”, „politycznych” i „literackich”; „straussistach naiwnych” i „myślących”; „moralizujących” i „niemoralizujących”; „Sokratejskich”, „Makiawelowskich” i „Nieztscheańskich”; „straussistach z wejścia frontowego, tylnego, bocznego i z drzwi obrotowych”; ,straussistach na pełny etat”, „,na pól etatu” i „sporadycznych” itd. (Fortin 1996: 318) ${ }^{21}$.

Tego rodzaju śmieszne zestawienia służą niewatpliwie uświadomieniu sobie przez badacza tego, iż jakakolwiek „monolityczna” wizja szkoły Straussowskiej byłaby z konieczności nadmiernym uproszczeniem (sam zaś ,założyciel” był, jak należy sądzić, świadom również tego, że utrzymanie jedności nie jest możliwe). Mając to na uwadze, można jednak wskazać istotny porządkujący rys podziału w łonie straussizmu; podziału opartego w mniejszym stopniu na przypadkowych afiliacjach, temperamentach i okolicznościowych przemianach życiorysu konkretnych postaci, w większym zaś na intelektualnym „pęknięciu”, gdy idzie o świadomą recepcję sedna nauczania Straussa. Sens tego podziału oddaje koncepcja tzw. geografii Straussowskiej. Uczniowie (uczniów) Straussa dzielą się tedy na reprezentantów ośrodków akademickich z ,wschodniego" (od Chicago po Boston) oraz „zachodniego” (głównie Kalifornia) wybrzeża Stanów Zjednoczonych.

$\mathrm{Na}$ koniec wskażemy jedynie kilka podstawowych wyróżników składających się na ten podział (Zuckert, Zuckert 2006: 228-259; Norton 2004: 7-8). Jeśli - za Catherine i Michaelem Zuckertami - zdecydujemy się uwzględnić jeszcze komponent środkowy, to wówczas wyłoni się potrójny obraz współczesnych straussistów: tych ze wschodniego wybrzeża, kojarzonych z zanurzeniem w literaturze pięknej i intensywnie wyrażana krytyką współczesnej kultury amerykańskiej; tych z zachodniego wybrzeża, egzegetów i apologetów reinterpretowanych zasad ustroju amerykańskiego, sięgających do arystotelizmu i dość silnie afiliowanych na amerykańskiej scenie politycznej w pobliżu chrześcijańskiej prawicy; wreszcie - przedstawicieli „środkowego zachodu”, najmniej rozpoznawanych i zarazem najbardziej oddalających się od Straussowskiego leitmotivu przewagi myśli klasycznej nad nowoczesna; do tego odłamu należałby m.in. Martin Diamond.

\footnotetext{
${ }^{21}$ Sam Fortin, teolog-asumpcjonista, zdaje się z aprobatą przyjmować określenie go jako ,jedynego w świecie, a przynajmniej najbardziej widocznego i otwarcie przemawiającego, Straussowskiego teologa" (Fortin 1996: ix).
} 
Z kolei w bardziej wyrazistej wersji dualistycznej (Ceaser 2008: 71) różnice byłyby następujące: po stronie „wschodu” znajdujemy określenie źródła kryzysu nowoczesności zarówno w obrębie zjawisk intelektualnych pozytywizmu i historycyzmu, jak i nowoczesnej refleksji prawnonaturalnej, przez co rodzi się stanowisko krytyczne wobec fundamentalnych zasad ustroju amerykańskiego, w praktyce (nauczania egzoterycznego) bliskie jednak podejściu komunitarystycznemu; na „zachodzie” kryzys łączy się z pozytywizmem i historycyzmem, ale nie z prawnonaturalnym fundamentem ustroju amerykańskiego, rozwijając tedy opcję republikanizmu opartego na zreinterpretowanej koncepcji naturalnych uprawnień; styl pisarski przedstawicieli „wschodu” jest bardziej nieprzewidywalny i wyrafinowany; w oczach „zachodu” pojęcie „natury” łączy się z wizją naturalnego ładu zbliżonego do „kodeksu” tomistycznego, podczas gdy na „wschodzie” w grę wchodzi jedynie rozpoznanie naturalnej hierarchii celów (życie polityczne a vita conteplativa); ,wschód” ceni raczej samą konstytucję, ,zachód” - Deklarację Niepodległości; „,wschód” zdradza fascynację stanowiskiem Tocqueville’a, „zachód” zaś Jeffersona i - poddanego właściwej reinterpretacji - Locke'a. Wreszcie, w kwestii wizerunku publicznego - jak trafnie wskazuje James Ceaser - „wschód jest bardziej filozoficzny, zachód bardziej polityczny”. Dla „dalekiego wschodu”

polityka filozoficzna jest dużo ważniejsza od filozofii polityki. Politologia ma być dzisiaj uprawiana tylko jako sposób ochrony filozofii, przez przypadek zadomowionej w dzisiejszej Ameryce głównie na wydziałach politologii. Przedstawiciele wschodu zapraszają mówców, by wypowiadali się na tematy polityczne i następnie szydzą z nich za to, że raczyli skupić się na rzeczywistym świecie (Ceaser 2008: 71).

Z kolei o „dalekim zachodzie”

mówi się nieraz, że jest zainteresowany tylko „ustrojem” [the regime] i porzucił zupełnie filozofię. Przedstawiciele zachodu wyrażaja większy podziw dla mężów stanu, niż dla filozofów [...]. Zapraszają oni mówców, by wypowiadali się na rozmaite tematy filozoficzne, potem jednak są rozczarowani tym, że nie spędzono więcej czasu przy rozkładaniu na czynniki pierwsze Deklaracji i Lincolna (Ceaser 2008: 71).

Mielibyśmy zatem do czynienia z dosyć wiernym odzwierciedleniem w sferze praxis (tj. podziałów środowiskowych w ramach amerykańskiego życia intelektualnego noszącego w sobie potencjał oddziaływania na życie polityczne ${ }^{22}$ ) zasadniczego napięcia między filozofią a „miastem”

\footnotetext{
${ }^{22}$ W tym kontekście, abstrahując od przytaczania długiej listy straussistów zaangażowanych w życie polityczne, warto zwrócić uwagę na krótki, autobiograficzny tekst napisany przez ucznia Blooma, który związał się z administracją - nie republikańską wszak, lecz kierowaną przez demokratów (Galston 1999: 429-437).
} 
(„Prawości” i „Wiary”) wskazywanego stale przez Straussa na podstawie jego rozważań problemu teologiczno-politycznego. Jednakże to, co dla Mistrza zdaje się stanowić nade wszystko zagadnienie uprawomocnienia filozofii jako drogi życia naznaczonej przez sceptyczną konstatację indywidualnej niewiary, dla jego najbardziej znanych uczniów staje się podstawa albo eksperymentującej $\mathrm{z}$ podwójnym nauczaniem - tyleż wyniosłej, ile nostalgicznej - obrony własnej wizji vita contemplativa (przy równoczesnym, problematycznym utożsamieniu tego, co objawione, z poezją czy literaturą kształtująca zdroworozsądkowy styl życia obywatela), albo też szczególnych prób łączenia filozofii z życiem politycznym (o którym wiadomo, że opiera się na wierze czy opinii), prowadzących do syntezy. Taka synteza, odrzucona przez samego Straussa, wynika z chęci wskazania racjonalnego uzasadnienia dla wiary w uniwersalne dobro, jakie rzekomo ucieleśnia się w ustroju amerykańskim; uzasadnienia, które nie mogło być dostarczone przez empirycznie zorientowanych, „naukowych” politologów reprezentujących „tradycję” XX-wieczną - tym bardziej niezainteresowanych apologia życia filozoficznego.

Bibliografia:

/// Anastaplo, George. 1999. Leo Strauss at the University of Chicago. W: K.L. Deutsch, J.A. Murley (ed.). Leo Strauss, the Straussians, and the American Regime. Lanham: Rowman \& LittleField Publishers, Inc., s. 3-31.

/// Arkes, Hadley. 1999. Strauss on Our Minds. W: K.L. Deutsch, J.A. Murley (ed.). Leo Strauss, the Straussians, and the American Regime. Lanham: Rowman \& Little Field Publishers, Inc., s. 69-89.

/// Batniztky, Leora. 2006. Leo Strauss and Emmanuel Levinas: Philosophy and the Politics of Revelation. New York: Cambridge University Press.

/// Behnegar, Nasser. 2003. Leo Strauss, Max Weber, and the Scientific Study of Politics. Chicago: University of Chicago Press.

/// Bellow, Saul. 1998. Suma po pržemyśleniach. Od niewyraźnej przeszłości do niepewnej prayssłłości. Tłum. T. Bieron. Poznań: Wydawnictwo „Zysk i S-ka”.

/// Bellow, Saul. 2001. Ravelstein. Tłum. Zbigniew Batko. Poznań: Dom Wydawniczy Rebis.

/// Benardete, Seth. 2002. Encounters \& Reflections. Conversations with Seth Benardete. R. Burger (ed.). Chicago: The University of Chicago Press. 
/// Berns, Laurence, Braun, Eva. 1999. Leo Strauss at St. John's College (Annapolis). W: K.L. Deutsch, J.A. Murley (ed.). Leo Strauss, the Straussians, and the American Regime. Lanham: Rowman \& LittleField Publishers, Inc., s.31-37.

/// Bloom, Allan. 1991. Giants and Dwarfs. Essays 1960-1990. New York: Simon and Schuster.

/// Bloom, Allan. 1997. Umyst zamkniety. O tym, jak amerykanskie szkolnictwo wyżze zawiodto demokracje $i$ zubożyto dusze dzisiejszych studentów. Tłum. T. Bieroń. Poznań: Wydawnictwo „Zysk i S-ka”.

/// Butterworth, Charles. Leo Strauss in His Own Write: A Scholar First and Foremost. URL = http://www.bsos.umd.edu/gvpt/Theory/Transcript_ Butterworth.pdf; dostęp: 17 października 2011 r.

/// Ceaser, James W. 2008. The American Context of Leo Strauss's Natural Right and History. „Perspectives on Political Science” 37-2, s. 69-74.

/// Cropsey, Joseph (ed.). 1964. Ancients and Moderns: Essays on the Tradition of Political Philosophy in Honor of Leo Strauss, New York: Basic Books.

/// Dahnhauser, Werner J. 1995. Allan Bloom: A Reminiscence. W: Michael Palmer, Thomas Pangle (ed.). Political Philosophy and the Human Soul. Essays in Memory of Allan Bloom. Lanham: Rowman \& LittleField Publishers, Inc., s. $1-13$.

/// Dannhauser, Werner J. 2007. Na powrót stać sie naiwnym. Tłum. P. Marczewski. „Przegląd Polityczny” 84, s. 138-143.

/// Drury, Shadia. 1999. Leo Strauss and the American Right. New York: St. Martin's Press.

/// Easton, David. 1975. Analiza systemów politycznych. W: W. Derczyński, J. Szacki, A. Jasińska-Kania (red.). Elementy teorii socjologicznych. Warszawa: Państwowe Wydawnictwo Naukowe, s. 562-576.

/// Emberley, Peter, Cooper, Barry (ed.). 2004. Faith and Political Philosophy: The Correspondence Between Leo Strauss and Eric Voegelin, 1934-1964. Columbia: University of Missouri Press.

/// Fortin, Ernest L. 1996. Classical Christianity and the Political Order: Reflections on the Theologico-Political Problem. Lanham: Rowman \& LittleField Publishers, Inc.

/// Galston, William A. 1999. A Student of Leo Strauss in the Clinton Administration. W: K.L. Deutsch, J.A. Murley (ed.). Leo Strauss, the Straussians, and the American Regime. Lanham: Rowman \& LittleField Publishers, Inc., s. 429-437.

/// Gilbert, Barry. 2006. Leo Strauss and his Legacy. „Juniata Voices” 6, s. $113-130$. 
/// Gunnell, John G. Political Theory and Politics: The Case of Leo Strauss and Liberal Democracy. W: K.L. Deutsch, W. Soffer (ed.). The Crisis of Liberal Democracy: A Straussian Perspective. Albany: State University of New York Press, s. 68-87.

/// Jaffa, Harry V. 1999. Strauss at One Hundred. W: K.L. Deutsch, J.A. Murley (ed.). Leo Strauss, the Straussians, and the American Regime. Lanham: Rowman \& LittleField Publishers, Inc., s. 41-48.

/// Jaffa, Harry V. The Legacy of Leo Strauss Defended. URL = http://www. claremond.org/publications/pageid.2562/default.asp; dostęp: 17 października $2011 \mathrm{r}$.

/// Kinzel, Kill. 2002. Platonische Kulturkritik in Amerika. Studien zu Allan Blooms The Closing of the American Mind. Berlin: Duncker \& Humblot.

/// Lilla, Mark. 2007. Mistr. Zamkniecie Straussowskiego umystu. Tłum. A. Lipszyc. „Przegląd Polityczny” 81: 135-140.

/// Mansfield, Harvey C. Jr. 1978. The Spirit of Liberalism. Cambridge: Harvard University Press.

/// Mansfield, Harvey C. Jr. 1991. America's Constitutional Soul. Baltimore: Johns Hopkins University Press.

/// Mansfield, Harvey C. Jr. 1996. Machiavelli's Virtue. Chicago: The University of Chicago Press.

/// Meier, Heinrich. 2006. Leo Strauss and the Theologico-Political Problem. Tłum. M. Brainard. Cambridge: Cambridge University Press.

/// Mordarski, Ryszard. 2007. Klasyczny racjonalizm polityczny w ujecin Leo Straussa. Bydgoszcz: Wydawnictwo Uniwersytetu Kazimierza Wielkiego.

/// Norton, Anne. 2004. Leo Strauss and the Politics of American Empire. New Haven-London: Yale University Press.

/// Orr, Susan. 1996. Strauss, Reason, and Revelation: Unraveling the Essential Question. W: D. Novak (ed.). Leo Strauss and Judaism: Jerusalem and Athens Critically Revisited. Lanham: Rowman \& Little Field Publishers, Inc., s. 25-53.

/// Pangle, Thomas L. 1989. Editor's Introduction. W: L. Strauss. The Rebirth of Classical Political Rationalism: An Introduction to the Thought of Leo Strauss. Chicago: The University of Chicago Press, s. VII-XXXVIII.

/// Pangle, Thomas L. 1994. Uszlachetnianie demokracji. Wyzpanie epoki postmodernistycznej. Tłum. M. Klimowicz. Kraków: Społeczny Instytut Wydawniczy „Znak”.

/// Rosen, Stanley. 1998. Hermenentyka jako polityka. Tłum. P. Maciejko. Warszawa: Fundacja Aletheia. 
/// Rosen, Stanley. 2007. Leo Strauss w Chicago. Tłum. A. Lipszyc. „Przegląd Polityczny" 84, s. 148-154.

/// Sabine, George H. 1961. A History of Political Theory. New York: Holt, Rinehart and Winston.

/// Smith, Gregory Bruce. 1999. Athens and Washington: Leo Strauss and the American Regime. W: K.L. Deutsch, J.A. Murley (ed.). Leo Strauss, the Straussians, and the American Regime. Lanham: Rowman \& LittleField Publishers, Inc., s. $103-127$.

/// Smith, Stephen. 2006. Reading Leo Strauss: Politics, Philosophy, Judaism. Chicago: The University of Chicago Press.

/// Söllner, Alfons. 1997. Leo Strauss: German Origin and American Impact. W: P. Graf Kielmansegg, H. Mewes, E. Glaser-Schmidt (ed.). Hannah Arendt and Leo Strauss: German Émigrés and American Political Thought after World War II. Cambridge: Cambridge University Press, s. 121-137.

/// Storing, Herbert J. (ed.). 1962. Essays on the Scientific Study of Politics. New York: Holt, Rinehart and Winston.

/// Strauss, Leo. 1954. On a Forgotten Kind of Writing, „Chicago Review” 8-1 (Winter/Spring), s. 64-75.

/// Strauss, Leo. 1969. Prawo naturalne w swietle bistorii. Tłum. T. Górski. Warszawa: Instytut Wydawniczy PAX.

/// Strauss, Leo. 1989. Liberalism Ancient and Modern. Ithaca: Cornell University Press.

/// Strauss, Leo. 1997. Philosophie und Gesetz - Frühe Schriften. H. Meier, W. Meier (ed.). Stuttgart-Weimar: Verlag J.B. Metzler.

/// Strauss, Leo. 1998. Sokratejskie pytania. Eseje wybrane. Tłum. P. Maciejko. Warszawa: Fundacja Aletheia.

/// Strauss, Leo. 2008. Hobbes' politische Wissenschaft und zugebörige SchriftenBriefe. H. Meier, W. Meier (ed.). Stuttgart-Weimar: Verlag J.B. Metzler.

/// Strauss, Leo. 2008. Miasto i čłowiek. Tłum. M. Warchala. „Przegląd Polityczny" 87, s. 163-168.

/// Strauss, Leo. 2009. O tyranii. Tłum. P. Armada, A Górnisiewicz. Kraków: Wydawnictwo Uniwersytetu Jagiellońskiego.

/// Strauss, Leo, Cropsey, Joseph (ed.). 1963. History of Political Philosophy. Chicago: University of Chicago Press.

/// Tanguay, Daniel. 2007. Leo Strauss: An Intellectual Biography. Tłum. Ch. Nadon. New Haven: Yale University Press.

/// Tarcov, Nathan. 1983. Philosophy \& History: Tradition and Interpretation in the Work of Leo Strauss. „Polity” 16-1 (Autumn), s. 5-29. 
/// Weinstein, Kenneth R. 2007. Korzenie filozoficzne. Leo Strauss a wojna w Iraku. Tłum. T. Żyro. W: I. Stelzer (red.), Neokonserwatyzm. Warszawa: Wydawnictwa Akademickie i Profesjonalne.

/// West, Thomas G. 1984. Defending Socrates and Defending Politics. W: Th.B. Silver, P.W. Schramm (ed.). Natural Right and Political Right: Essays in Honor of Harry Jaffa. Durham: Carolina Academic Press.

/// Zuckert, Catherine, Zuckert, Michael. 2006. The Truth about Leo Strauss. Political Philosophy and American Democracy. Chicago: The University of Chicago Press.

\section{/// Abstrakt:}

Artykuł ten omawia niektóre zasadnicze rysy tzw. szkoły Straussowskiej w kontekście głębokiej spuścizny intelektualnej jej założyciela. Leo Strauss był w latach 30. uchodźca z nazistowskich Niemiec i następnie osiadł w USA, gdzie zyskał sławę jako wybitny nauczyciel w dziedzinie nauk politycznych, zwłaszcza na University of Chicago. Choć zajmował się głównie nadzwyczaj złożonym zagadnieniem relacji między filozofią a prawem, tj. życiem w pełni oddanym poszukiwaniu mądrości z jednej strony i życiem politycznym opartym na autorytecie religijnym z drugiej, przez co był raczej nierozumiany przez swych akademickich kolegów, zdobył niemal bezgraniczne uwielbienie swoich studentów. Wyłonienie się szkoły Straussowskiej jawi się jako rezultat rozmyślnego działania Straussa, który chciał ugruntować pewnego rodzaju dostęp do rdzenia własnej myśli. Wziąwszy pod rozwage poważne zróżnicowanie w łonie szkoły Straussowskiej, należy zastanowić się nad tym, w jakiej mierze uczniowie Straussa zdołali sprostać intelektualnemu wyzwaniu swego mistrza.

Słowa kluczowe:

Leo Strauss, szkoła Straussowska, rozum, objawienie, ezoteryzm

\section{/// Abstract:}

Between the Theologico-Political Problem and the Faith of Political Scientist.

\section{Some Remarks Concerning the Straussian School}

The article examines some basic tenets of the so-called Straussian school in the context of the profound intellectual legacy of its founder. Leo Strauss had fled from Nazi Germany in the 1930. and after being naturalized in the 
US he emerged as an outstanding teacher in political science, especially at the University of Chicago. While he was mainly concerned with the most complicated issue of the relation between philosophy and Law, i.e. the life entirely devoted to the search for wisdom on the one hand and the political life thoroughly based on the religious authority on the other hand, and thus hardly understood by his fellow scholars, he gained an almost unlimited admiration from his students. The emergence of the Straussian school appears to be a result of a deliberate action of Strauss who wanted to establish a way of access to the core of his thinking. Having taken into consideration how seriously is the Straussian school differentiated, we should reflect upon a degree to which the pupils of Strauss have managed to live up to the intellectual challenge posed by their master.

Keywords:

Leo Strauss, Straussian school, reason, revelation, esoterism 